\title{
Secular Education and the Political Socialization of Muslim Children ${ }^{1}$
}

As discussions of the "New World Order" intensify, Muslims around the world are increasingly questioning the relevance of this phrase to their lives and to the future of the ummah. For many Muslims, the popularization of this term signals a need to reexamine those processes that shape the transmission of the Islamic worldview from one generation to the next. The proposed "New World Order" seems much too reminiscent of the "Old World Order," an economic and political order characterized by the economic subservience and political impotency of most of the Muslim world. Muslim social scientists are beginning to examine those processes and factors that might create the kind of "New World Order" that liberates rather than oppresses Muslims.

One area of inquiry that must be addressed is that of political socialization, as it is a phenomenon that occurs within virtually every human culture. In essence, it is a process that involves the individual's acquisition of socially and culturally approved attitudes, values, beliefs, and behaviors as regards the political world. As a social science subspecialty, it represents a convergence between political science and child development. Much of the literature dealing with political socialization therefore focuses on the institutions and mechanisms through which children are politically socialized over time.

Within the Muslim world, the study of political socialization is critical to acquiring an understanding of how Muslim children learn about the multidimensional nature of the political world. How do they learn about politics? What kinds of political socialization models might be developed to reflect their experience? What are the relative effects of institutions like the family and school on their political socialization? These are just a few of the questions that must be addressed within an approach to political socialization that reflects the cultural integrity of Muslims.

This paper will explore the potential impact of secular education on the political socialization of Muslim children. It will begin with a discussion of a variety of political socialization models that have been developed in the West. Nationalism, as a central dimension of political socialization, will be discussed with particular emphasis placed on how schools promote nationalism in children. The conflict between nationalistic and Islamic identities will be explored as it is manifested in the secularized educational curricula. Islam-

'An earlier version of this research note was presented at the International Conference of the Association of Muslim Social Scientists held in Karachi, Pakistan, during 3-7 January 1992. 
ic education will be described as an alternative to contemporary secularized education and also as a vehicle through which a more Islamized political socialization of Muslim children might occur.

\section{Definitions and Models of Political Socialization}

In defining political socialization, Easton and Dennis $(1965,50)$ have suggested that "political socialization refers to the ways in which a society transmits political orientation-knowledge, attitudes or norms and values from generation to generation." Massey $(1976,4)$ has noted that:

....political socialization is one of the requisite functions whose performance is necessary in any political system for that system to be capable of maintaining itself in an operation. The function performed by the political socialization process is the transmission to the members of the system, from generation to generation, of a common store of orientations toward politics. These orientations include beliefs and values about the manifold aspects of the political system, such as the system itself as a general object, the government (or output) institution and the political (or input) institutions, and the self and others as actors in the political process. The prevailing patterns of such orientation in a society constitute its "political culture."

Hess and Torney (1967) list four political socialization process models. The first model, the Accumulation Model, is based on the behaviorist postulate that the child is a passive recipient of knowledge and data (in this case knowledge and information about the political world). If parents and teachers gradually expose children to acceptable ideas, values, and attitudes, they will be absorbed and ultimately expressed in adulthood. This model virtually ignores mediating variables such as the child's prior level of knowledge.

The second model, the Identification Model, also reflects a behavioristic orientation and assumes that the child imitates parental behavior in the expression of political values. This model, however, recognizes that teachers and peers are also vital reference groups and thus serve as sources of political values to be evaluated.

The third model, the Role Transfer Model, stresses the child's use of previous experiences to shape his/her perceptions of an orientation towards the political system. Experience and role performance within the family, the school, and one's peer group are thus generalized to the political arena.

The fourth model, the Cognitive Developmental Model, stresses the child's increasing ability to view the world, particularly the political world, in terms of abstractions and complex concepts. The ability to distinguish 
ideals from reality and the increased use of reasoning abilities to make political judgments are emphasized by this model.

These Western models of political socialization are not adequate conceptual frameworks for examining the socialization of Muslim children. Basing himself on verses from the Qur'an, Rashid $(1990,17)$ has suggested that an Islamic conceptual framework would view socialization as "the process of maintaining the child's Muslim identity from infancy into adulthood":

Socialization for Muslims involves providing children with an understanding of their purpose in life (submission to God, 51:56, 2:21, $31: 22$ ), the goal of their life (return to God, 6:60), and a means of accomplishing the purpose and achieving the goal (seerat al mustaqeem or the straight path outlined in the Qur'an and the Sunnah of Prophet Muhammad, peace be upon him, 6:153, 37:21). Thus from an Islamic frame of reference or world view, Western theoretical approaches to socialization are incomplete in that they fail to articulate a relationship between the agents and mechanisms of socialization and an ultimate goal of the process itself (Ibid., 17).

An Islamic perspective on the political socialization process would clearly emerge out of an Islamic view of socialization in general. A framework for evaluating successful political socialization in Muslims would, therefore, have to apply the standard of Qur'an and Sunnah to those institutions responsible for the process. The family would be the initial agent of socialization, as it would naturally be expected that children would internalize and ultimately manifest the political orientation of their parents, whether Islamic or otherwise, while they are young. However as they grow up and mature, their schools and peers have an increasing influence. It is the role of schools in political socialization that must be of concern to Muslims, for they play a very prominent role vis-à-vis political knowledge.

\section{School, Socialization, and Nationalism}

In his analysis of the school's role in the socialization process, Schwartz (1975) distinguishes between gemeinschaft and gesellschaft groups. Gemeinschaft (from the German word meaning "community") groups foster informal, spontaneous, and highly personal relationships that carry broad mutual obligations. Families and friendship units are gemeinschaft groups. Gesellschaft (from the German word meaning "organization" or "society") groups promote relatively formal, rational, and impersonal role relationships that carry limited mutual obligations. Schwartz states that the young child is initially socialized by the family into gemeinschaft patterns of behavior while learning gesell- 
schaft patterns at school. A school therefore serve as a transition institution by increasingly giving the child opportunities to behave in more reflective of adult social and political life. Schwartz $(1975,18)$ notes this transition:

In general, the relative influence of the family on political values diminishes as other people and groups take on more significance. Political values emerge, then, from the cumulative experiences-both political and nonpolitical, spontaneous and formally structured of early childhood, adolescence and adulthood.

While the West's secularization of political life has at least theoretically removed its religious dimension, no such dichotomy or dualism exists in Islam. Within the Islamic worldview, religious life and political life are one. If the political socialization of Muslim children is to be truly Islamic, there must be consistency between the values initially taught in the home and those promoted within the school. If, over time, Muslim children begin to view political life as somehow distinct from religious life, then ultimately the norms and values of politics will govern the dimensions of their life.

Political norms are usually incorporated into formal curricula in courses such as civics, social problems and history. For example, a study of political socialization provided by elementary schools in eight representative American cities documents the fact that, not only do curricula contain political values such as the importance of elections in democratic societies, they also contain political norms such as the rules of morality that surround elections and the obligation to express solidarity behind winning candidates (Ibid., 18).

The "rules of morality" promoted by the political socialization agenda of the school are embedded in a curriculum that has as its primary objective the creation of a citizen that will support the existing order. This existing order is one that promotes a primary loyalty to the nation-state, i.e., the country of one's citizenship. At an ideological level, loyalty to the nation-state is indistinguishable from nationalism. Thus the major political socialization function of schools within the context of Western culture is the perpetuation of nationalism, by which is meant loyalty to the nation-state.

Smith $(1971,21)$ has suggested that the core doctrine of nationalism is rooted in seven basic propositions: 1) Humanity is naturally divided into nations; 2) Each nation has its own peculiar character; 3) The source of all political power is the nation, the whole collectively; 4) For freedom and selfrealization, individuals must identify with a nation; 5) Nations can only be fulfilled in their own states; 6) Loyalty to the nation-state overrides other 
loyalties; 7) The primary condition of global freedom and harmony is the strengthening of the nation-state.

While Muslims would certainly accept propositions one and two, as they conform with the Qur'an (i.e., 49:13), propositions three through seven must be rejected on equally Islamic grounds. As a secular educational system promotes loyalty to the nation as the highest good, Muslim children are in essence being forced to deny the veracity of the Qur'an and ignore its supremacy over any law or ideology imposed by the nation-state. Thus it is essential that Muslims demand the implementation of Islamic education wherever there are Muslim children who must be socialized into the worldview and way of life ordained by God.

\section{Islamic Education: A Mechanism for Muslim Political Socialization}

In the Qur'an, we find the following statements: "I have only created Jinns and men that they may serve me" (51:56), and "Read! In the name of thy Lord and Cherisher, Who created - Created man out of a (mere) clot of congealed blood. Read! And thy Lord is Most Bountiful - He who taught (the use of) the Pen - Taught man that which he knew not" (96:1-5).

These verses form the basis for Islamic education in its broadest sense: an educational ideology that stresses 1 ) the human being's purpose for living (to worship God) and 2) the major means that God has provided for acquiring knowledge (the pen or the written word). Sarwar $(1984,7-8)$ has provided the following definition of Islamic education:

Islamic education may be defined as a system which transmits the revealed and acquired knowledge to the younger generation of Muslims in order to prepare them for life and enable them to discharge their duties as Kalifah (Vicegerent or Agent) of Allah on this earth with the sole aim of achieving success here and in the hereafter (Akhirah).... Islamic education is a total and complete system which does not separate the mundane affairs of life from the moral and spiritual aspects.

This reorganization of the Islamic process of education as a "total and complete system" has clear implications for the different kinds of political socialization that would occur in a secular, as opposed to an Islamic, system. Whereas the secular approach to education fosters primary allegiance to the nation-state and thus reinforces and promotes nationalism, the Islamic approach to education uses the Qur'an and the Sunnah to orient the political socialization of young Muslims. God says: "Oh Mankind! We created you from 
a single (pair) of a male and a female, and made you into nations and tribes, that you may know each other...." (49:13). In his last sermon, the Prophet stated clearly that no nation, race, or tribe is superior to another except that it possesses more righteousness. The political socialization of Muslim children, therefore, as reflected in their education, must foster an allegiance, first and foremost, to the Muslim ummah.

Islam is the glue with which God binds together the hearts of the believers. Thus Islamic education must be the framework through which Muslim children are socialized into a political consciousness. The secular emphasis on national consciousness as one's primary identity can only serve to divide Muslims into arbitrary and un-Islamic groupings. The following verses make this quite clear:

And hold fast, all together, by the rope which Allah (stretches out for you), and be not divided among yourselves; and remember with gratitude Allah's favor on you; for you were enemies and He joined your hearts in love, so that by His grace, ye became brethren (Qur'an 3:103).

Verily, this brotherhood of yours is a single brotherhood, and I am your Lord and Cherisher: therefore Serve Me (and no other) (Qur'an 21:92).

It is clear from the Qur'an that God has ordained that Muslims see themselves as one community (ummah). It is equally clear that the contemporary Muslim world is made up of many artificial nation-states created by Western colonial powers whose sole objective has been the continued exploitation of Muslim resources through an assortment of divide and conquer methods. Education will continue to be a tool for promoting divisiveness among Muslims as long as it is stripped of its base in Qur'an and Sunnah. The secularization of the education of Muslim children can only result in the secularization of young Muslim minds, which in itself can only result in a type of political socialization that is a mirror image of that which occurs in the West.

As long as Muslims continue to view "modernization" as being synonymous with "Westernization," there will be efforts to secularize the education of Muslim children and structure it along Western lines. The dominant ideological orientation of education in Muslim countries will not, therefore, be Islamic; rather it will be a secularized perspective that has established a fundamental duality between religion and politics, and between religion and all other aspects of life. Implementing the Sharī'ah, developing an Islamic banking system, or promoting an Islamic concept of democracy based on shürā (mutual consultation) would therefore be seen as "extremist" or "fundamental- 
ist" and as being somehow in conflict with aspirations toward "modernism." Muslim countries must look with a critical eye at any attempt to impose an educational strategy that places Islam in a peripheral position. The "religion" of secular humanism views the human mind as the deity, the object of reverence. An educational doctrine that replaces Islam with secularism can only result in a progressive weakening of the ummah. The implementation of an Islamic educational agenda, however, currently faces a number of political and economic obstacles that must be overcome if, ultimately, Muslims are to assume control for the socialization of their children.

One of the first obstacles to this is the inability of Muslims to recognize the pervasiveness of un-Islamic ideologies when it comes to the education of their children. Brembeck $(1969,200)$ has discussed the influence of American educational ideology and practice in the educational system of developing countries. American public schools have been used as a vehicle of "national integration," a mechanism for diffusing cultural distinction that might threaten national identity. This focus on nationhood, he feels, is a lesson well learned in the developing world.

The schools of developing nations are being used as never before to identify, develop and transmit the nation's heritages.... The flag is saluted with special pride and the national anthem is sung with a loud voice. The books are full of accounts of national heroes and the culture's legends and the children are called upon to emulate the heroes and to be worthy citizens.

The use of schools to build national loyalties is surely not an American invention ... but we were probably the first to use the schools on the grand scale of universal education as unifying symbols of nationhood. The lesson of our experience has not been lost on the new nations which are now confronted with the same task of creating common loyalties among conflicting tribal and regional interests as a basis for their survival.

What Brembeck fails to mention, however, is that these "new nations" are for the most part creations of the colonial and imperialist powers of the past. For predominantly Muslim nations, the overwhelming majority of which are in Africa and Asia, this creation of "common loyalties" within nations often leads to conflict and suspicion between predominantly Muslim countries. The Islamic concept of one ummah has been subordinated to nationalistic interests, interests that are typically consistent with continued imperialistic domination.

While Muslims must increasingly recognize the dangers of secular education, they must also make some serious efforts to develop the kinds of Is- 
lamic curricula that can be used in a variety of national contexts.

The content of primary school curricula is similar throughout the world, including the Muslim world. Benovat and Kamens (1989), for example, studied curricular emphasis in 130 countries and found that not only were the same basic subjects taught, but that the relative emphases given to the various subject areas were similar. Lockhead and Verspoor $(1990,31)$, however, make a distinction between the "intended" or official curriculum and the "implemented" curriculum, by which is meant the one that teachers actually use.

The official, intended curriculum only establishes broad guidelines for instruction. Actual curriculum implementation is carried out by teachers using textbooks. In textbooks, the scope of the subject matter to be taught is defined and its sequence for instruction is laid out. Textbooks are the major-if not only-definition of the curriculum in most developing countries.

Textbooks will continue to play a primary role in the curriculum of Muslim countries for a long time. Thus it is essential that Muslims begin to produce their own textbooks, textbooks grounded in Islamized knowledge and designed to produce an Islamic worldview in the young. As the curriculum and overall process of education becomes increasingly Islamic, we can expect a corresponding shift in the political socialization process. Muslim children exposed to an Islamic education will no longer be plagued by the dualism that characterizes the Western worldview. Their orientation to the political world will be dictated by the political requirements of the Qur'an and the Sunnah.

\section{Overcoming Barriers to Islamic Political Socialization}

At the present time, there are serious barriers to the widespread implementation of a program of Islamic education that would result in Islamic political socialization. The process of secularization has become so pervasive in many predominantly Muslim countries that to offer Islamic education as an alternative is viewed as both backwards and antimodern. The dual educational system (secular vs. religious) established by colonial powers to undermine Islam's influence is so entrenched that many of those who call themselves Muslim, and yet call out the phrase "no religion in politics," fail to see the contradiction. It is essential that Muslims who recognize the need for a unified educational system based firmly on the ideological foundation of the Qur'an and the Sunnah begin to coalesce and communicate with one another on a regular basis. International conferences must be held as often as possible so that Muslims from around the world can meet and discuss problems and progress in the implementation of Islamic education in their native lands. As 
vehicles for communication are broadened, Muslims should see an increased demand for truly Islamic education.

Another barrier to Islamic education, and thus to Islamic political socialization as well, is the influence of external agencies on the educational policies of predominantly Muslim countries. As mentioned earlier, the United States has attempted to play a major role in molding the educational philosophy of many developing countries to reflect the Euro-American worldview. Muslims must establish a set of criteria, again grounded in the Qur'an and the Sunnah, that limit the influence of external agencies, particularly those whose policies and practices have proven to be inimical to Muslim interests. Where restructuring education along Western secular lines is made a condition for certain types of financial assistance, Muslims must be prepared to say that the Islamic character of the next generation is not for sale. While some short-term sacrifices may be required, in the long run self-sufficiency is the only Islamic option available to Muslims. Anything less than educational self-sufficiency will result in a continued perpetuation of a colonized mentality that has become comfortable with economic dependency, cultural confusion, and a secularized view of the world. Making educational self-sufficiency a priority is a major step in Islamizing the political socialization of young Muslims. Once this process has begun, young Muslims will gradually start to look to themselves, under the guidance of the Qur'an and the Sunnah, for the right solutions to the problems facing the ummah.

\section{Conclusion}

In conclusion, the "New World Order" is a clear reality for both the Muslim and non-Muslim worlds. The death of Communism as a major ideology, the demise of the Soviet Union as a superpower, the unification of the European Economic Community, the revival of Islam in the hearts and minds of Muslims across the globe-all of these are evidence of a world order that is quickly being restructured. This remaking of the world, however, will be a generational process for which upcoming generations of Muslims must be prepared. We must therefore pay close attention to how they are politically socialized from early childhood and on into adulthood. Recognizing the danger posed to an Islamic political socialization by secular education is a first step. Only by an Islamic educational process that stresses both competence in the "modern" disciplines and a consciousness of one's duty to God can the next generation of Muslims take its rightful place as a major player in the "New World Order." 


\section{References}

Brembeck, C.S. "United States Industrial Designs Woven into the Fabric of International Education." In The United States and International Education, edited by H. Shane. Chicago: National Society for the Study of Education, 1969.

Benavot, A. and D. Kamens. "The Curricular Content of Primary Education in Developing Countries." Policy, Planning and Research Working Papers. Education and Employment, WP5, no. 237. Washington, D.C.: Population and Human Resources, 1989.

Easton, D. and J. Dennis. "The Child's Image of Government." Annals of the American Academy of Political and Social Science, no. 36 (1965): 40-51.

Hess, R. and J. Torney. The Development of Political Attitudes in Children. Chicago: Aldine, 1967.

Lockhead, M. and A. Verspoor. Improving Primary Education in Developing Countries: A Review of Policy Options. Washington, D.C.: International Bank for Reconstruction and Development (The World Bank), 1990.

Massey, J. Youth and Politics in Japan. Lexington: D.C. Heath, 1976.

Rashid, H. In Search of the Path: Socialization. Education and the African-American Muslim. Capitol Heights, MD: Imania Publications, 1990.

Sarwar, G. Syllabus and Guidelines for Islamic Teaching. London: The Muslim Educational Trust, 1984.

Smith, A. Theories of Nationalism. London: Harper and Row, 1971.

Schwartz, A. The Schools and Socialization. New York: Harper and Row, 1975.

Hakim M. Rashid Associate Professor and Chairperson Department of Human Development School of Education Howard University, Washington, DC. 